ELORE (ISSN 1456-3010), vol. 15 - 2/2008.

Julkaisija: Suomen Kansantietouden Tutkijain Seura ry.

[http://www.elore.fi/arkisto/2_08/mah_b_2_08.pdf]

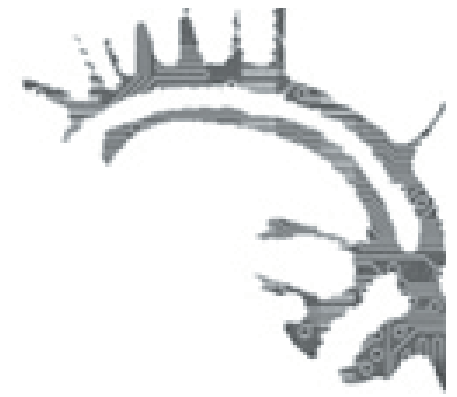

\title{
KIRJA-ARVIO: \\ ONNETTOMIEN JA SOPEUTUMATTOMIEN NAISTEN TEKSTEJÄ
}

Tuohela, Kirsi 2008: Huhtikuun tekstit. Kolmen naisen koettu ja kirjoitettu melankolia 1870-1900. Suomalaisen Kirjallisuuden Seuran Toimituksia 1161. Helsinki: Suomalaisen Kirjallisuuden Seura. 373 sivua.

\section{Tiina Mahlamäki}

\begin{abstract}
"Huhtikuu on kuukausista julmin, se työntää sireenejä kuolleesta maasta, sekoittaa muiston ja pyyteen, kiihoittaa uneliaita juuria kevätsateella", kirjoitti unohtumattomasti runoilija ja kriitikko T. S. Eliot $(1972,83)$ vuonna 1922. Kulttuurihistorioitsija Kirsi Tuohela taas tarkastelee väitöskirjassaan huhtikuun teksteiksi nimeämiään julkaistuja ja julkaisemattomia tekstejä, joita ovat tuottaneet kolme 1800-luvun lopun murroskaudella kirjoittanutta, melankoliasta kärsinyttä naista: Victoria Benedictsson, Amalie Skram ja Laura Marholm. Huhtikuun tekstit tarkoittavat Tuohelalla melankoliaa ja alakuloa ilmentäviä tai sitä kommentoivia kirjoituksia. Tuohelan työssä huhtikuu ei viittaakaan Eliotiin vaan L. Onervan Inari-romaaniin (1913), jonka päähenkilöä kuvataan huhtikuun lapseksi "täynnä lakkaamatonta levottomuutta ja puolinaisuutta". Tällaisia ovat myös Tuohelan tutkimat naiset, joilla on "menneisyyden naisen hermosto ja sydän ja tulevaisuuden naisen järki ja tahto", jotka elävät ristiriidoissa, kärsivät sopeutumattomuudesta ja ovat onnettomia (s. 17). Vaikka yhteiskunnalliset olot ja naisen asema ja mahdollisuudet vaikuttaa elämäänsä ovatkin merkittävästi kehittyneet 1800-luvun lopulta, (nais)lukija saattaa helposti ryhtyä vertailemaan omaa elämäänsä näihin naisiin. Hyvin helposti tulee työtä lukiessa pohtineeksi omia kokemuksiaan ja tuntemuksiaan, sillä Tuohela tuo tutkimansa naiset hyvin intiimisti lukijaa lähelle: naisten elämykset ja kokemukset, tunteet, ilot ja erityisesti tuska tulevat lukijalle kovin tutuiksi ja tutkittavat naiset avautuvat lukijan eteen hyvin paljaina. Kirsi Tuohela kirjoittaa kaunista, ilmeikästä ja sujuvaa kieltä, jota on ilo lukea. Iloa hieman himmentävät lukuisat, miltei joka sivulta löytyvät kirjoitusvirheet.
\end{abstract}




\section{ONNETTOMIEN JA SOPEUTUMATTOMIEN NAISTEN TEKSTEJÄ}

\section{TUTKIMUSKOHTEENA MELANKOLINEN MINÄ}

Hubtikun tekstit on (kulttuuri)historiantutkimusta, mutta se ei ole kaukana kirjallisuudentutkimuksesta eivätkä sen lähestymistavat ole vieraita muullekaan kulttuurintutkimukselle. Teos on naisten kirjoittamisen kulttuurihistoriaa, naisten melankolian historiaa, modernisoituvan kulttuurin historiaa ja erityisesti sukupuoleen vakavasti suhtautuvaa naishistoriaa. Viime vuosina Turun yliopistosta on valmistunut lukuisia 1800-luvun ja 1900-luvun alun naiskirjailijoita ja -kirjoittajia käsitteleviä väitöskirjoja - tutkijoina esimerkiksi Heidi Grönstrand (2005), Kati Launis (2005), Maarit Leskelä-Kärki (2006) ja Kukku Melkas (2006). Käsillä oleva teos on valmistunut tiiviissä kontaktissa näihin kirjoittajiin, minkä näkyy tietyllä tavalla tuttuna kirjoittamisen, ajattelemisen ja tieteen tekemisen tapana. Tosin Tuohelan työn kontekstina on muista poiketen lähinnä Tanska, mutta ahkerasti (ja osin tarpeettomasti) kirjoittaja viittaa samaan aikaan tai myöhemmin Suomessa tapahtuneisiin rinnakkaisiin ilmiöihin tai kirjoitettuihin teoksiin, kuten myös mainitun tutkijaverkoston tuottamiin tulkintoihin.

Tuohelan tutkimusongelmana on tarkastella melankolisen minän tuottamista omaelämäkerrallisissa teksteissä. Lukijalle ei aivan tarkalleen selviä, miksi tarkastelun kohteeksi on valittu juuri nämä kolme naista - itse ainakin koen ongelmalliseksi kolmikon viimeisen, Laura Marholmin, suhteen muihin kirjoittajiin. Aineiston valinnan periaatteetkaan eivät aivan avaudu. Tutkimusaineistoksi on otettu hyvin monenlaisia tekstejä: kirjeitä, päiväkirjoja, sanomalehtiartikkeleita ja kaunokirjallisuutta. Valittujen tekstien yhteisenä nimittäjänä on omaelämäkerrallisuus. Aineistoa on hämmästyttävä määrä, mutta se on luonteeltaan hyvin hajanaista. Lisäksi Tuohela kohdistaa erilaisiin aineistoihin erilaisia lukutapoja. Esimerkiksi työn keskeistä käsitettä, melankoliaa, voi lähestyä niin henkilökohtaisena sairauden tunteena, neuvoteltavana sosiaalisena ja kulttuurisena määreenä, aikakauden kuvauksena kuin lääketieteellisenä diagnoosina. Työn otsikosta löytyvä aikarajaus, 1870-1900, on loppujen lopuksi melko viitteellinen, sillä kaikki käsitelty aineisto ei mahdu tähän aikaväliin. Olisi voinut puhua myös 1800-luvun lopusta.

Tutkimuksen keskeinen, otsikkoonkin nostettu teoreettinen käsite on melankolia. Melankoliaa ei tarkastella humoraaliopin valossa ihmisluonteena tai nesteiden epätasapainona, vaan melankolia nähdään tutkittavien identiteetin keskeisenä osana, kärsivän minän sairautena. Tai ehkä taustalla, näkymättömissä, on sittenkin humoraalioppi, sillä Tuohela tulkitsee tutkimillaan naisilla olevan melankolisen minän, melankolisen minuuden. Melankolia rinnastuu toisaalta masennukseen sellaisena kuin se nykyään ymmärretään, toisaalta vielä 1800-luvulla yleiseen hysteria-diagnoosiin, jolla leimattiin erilaisista psyykkisistä tai sosiaalisista ongelmista kärsiviä naisia ja johon sairauteen myös naiset näitä ongelmiaan pakenivat. Hysteria-käsitteen kulttuurihistoriaa on tarkastellut Anna Kortelainen Levoton nainen -teoksessaan (2003). Sekä Kortelaisen että Tuohelan töissä tulee kirkkaana esiin yhteiskunnallisten ja sosiaalisten tekijöiden vaikutus naisten mielen ja ruumiin sairauksiin. 


\section{Melankolisten NAISTEN SAIRAUSKERTOMUKSET}

Tuohela kirjoittaa aineistonsa pohjalta tutkimuskohteidensa sairaus- ja kirjoittajaelämäkerrat. Kaikki tutkitut naiset olivat tavalla tai toisella mieleltään hauraita ja sairaita, he kärsivät masennuksesta ja ahdistuksesta, jopa skitsofreniasta. Sairautta, sairastumista, sairaana elämistä ja olemista sekä selviytymistä tai sairauden alle uupumista he kaikki käsittelivät kirjoittamalla. He kirjoittivat kirjeitä, päiväkirjoja, lehtiartikkeleita, novelleja, romaaneja. Taustalla olivat miehet: aviomiehet ja rakastajat, jotka pettivät, jättivät, kohtelivat kaltoin eivätkä rakastaneet tarpeeksi. Taustalla on myös näiden naisten koko elämä: lapset, työ ja yhteiskunta. Vaatimukset, joita naiset eivät jaksaneet täyttää. Niin tuttua vielä tänäänkin: lapset sairastavat, työnteosta ei tule mitään, huolet, murheet ja taloudellinen ahdinko valvottavat.

Jokainen nainen käsitellään työssä erikseen, omana kokonaisuutenaan, ja "tapauskertomusten" alussa on luvun kohteena olevan naisen kuva. Jokainen nainen on kuvassa lapsensa kanssa. Tämä kuvien valinta hieman hämmästyttää. Yhtäältä siinä itsestään selvästi rakennetaan kytköstä naisen ja lapsen välillä, mutta toisaalta itse tekstit taas kertovat eri tarinaa. Victoria Benedictssonin ainoa biologinen tytär oli 15-vuotias äidin tappaessa itsensä. Tekstissä ei tytärtä mainita kuin muutaman kuukauden ikäisenä vauvana. Suuremman huomion saa pienokaisena kuollut tytär sekä tytärpuoli, joka kertomuksen perusteella joutuu suuressa märin huolehtimaan mieltään sairastavasta äitipuolestaan. Avioituessaan toisen kerran Amalie Skram jätti jälkeensä kaksi poikaa ensimmäisestä avioliitostaan, vaikka hän olikin eronsa yhteydessä taistellut lujasti heidän huoltajuudestaan; tyttärensä Johannan hän antoi muiden hoitoon pystyäkseen työskentelemään. Laura Marholm taas jätti pienen poikansa vuokraisännälleen, koska hänellä ja hänen puolisollaan ei ollut varaa pitää lasta. Sijoitus vuokraisännän luo kesti seitsemän vuotta! Kuvat näyttävät heidät kuitenkin huolehtivina ja rakastavina äiteinä.

Erityisesti ensimmäinen kertomuksista, Victoria Benedictssonin (1850-1888) tarina, on koskettava. Se on kertomus naisesta, joka ei sopeudu sukupuoleensa, ei avioliittoonsa, ei äitiyteensä. Hän on yksi niistä naisista, joka on "saanut roolin, johon ei mahdu". Hän halusi enemmän kuin mihin hänellä oli naisena mahdollisuuksia. Hän halusi elää vapaana kirjoittajana, mutta hänen kykynsä ja voimansa eivät riittäneet siihen. Hän valitti rahapulaansa, kanssaihmisten ymmärtämättömyyttä ja rakkauden puutetta. Lukijan katse kuitenkin huomaa, että hänen ulkoiset puitteensa olivat erittäin hyvässä kunnossa: rahapula ja yksinäisyys olivat hyvin suhteellisia, sillä hänellä oli jatkuvasti ympärillään ihmisiä, jotka huolehtivat hänestä. Victoria Benedictssonin sairauskertomus tuo selkeästi esiin sen, miten melankolia ja masennus usein tekevät ihmisestä itsekeskeisiä. Hän oli murtua rahapulaansa, vaikka itse asiassa eli taloudellisesti turvattua elämää. Kyse ei siis ole vain sukupuolesta vaan myös luokasta. Ja mielestäni on tärkeää muistaa, ettei masennus välttämättä tarvitse "oikeaa", ulkoisiin puitteisiin liittyvää syytä.

Tuohela keskittyy Benedictssonin kohdalla erityisesti tämän elämän loppuaikoihin, jolloin Benedictsson keskittyi valmistelemaan itsemurhaansa. Teksti hidastuu ja tiivistyy näihin viimeisiin vuosiin ja viimeisiin kirjoituksiin. Kyseessä ei olekaan elä- 


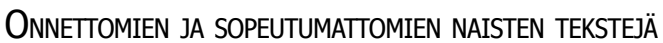

mäntarina vaan kuolemantarina; kaikki kerrottu kerrotaan suhteessa loppuratkaisuun, Victorian itsemurhaan. Tuohela asettaa tässä lukijansa eettisesti vaikeiden kysymysten eteen: Mikä oikeus meillä on seurata yksityiskohtaisen tarkasti sitä, miten toinen valmistautuu tappamaan itsensä? Mikä oikeus meillä on lukea intiimejä paljastustekstejä, yksityiseen käyttöön tarkoitettuja päiväkirjoja ja kirjeitä? Onko kaikkea, mitä tutkija löytää, sallittua käyttää tutkimuksessa? Mikä on meidän eettinen velvollisuutemme menneisyyden ihmisiä kohtaan? Tuohela (s. 24) perustelee Benedictssonin päiväkirjojen käyttöä sillä, että kyseessä "on poikkeuksellinen dokumentti, sellainen tarkka ja seikkaperäinen oman elämänväsymyksen erittely, jota on vaikea löytää muualta".

Toinen, ei aivan yhtä traaginen naiskohtalo, oli Amalie Skramilla (1846-1905), jonka tarinan myötä pääsemme tutustumaan 1800-luvun lopun mielisairaaloihin. Hän koki elämässään kaksi avioliittoa, kaksi pettävää puolisoa ja kaksi avioeroa. Hän joutui kahteen otteeseen mielisairaalahoitoon ja joutui kipeästi kokemaan 1800-luvun lopun mielisairaanhoidon alkeellisen ja rajoittuneen diagnostiikan sekä hoitoa ja parannusta tarjoamattomat hoitokeinot. Hän käsitteli sekä avioliittoja että mielisairaanhoitoa romaaneissaan, joissa hyödynsi yksityiskohtaisesti niin omia kuin potilastovereittensa kokemuksia sekä mustamaalasi häntä hoitaneen lääkärin. Hän kuvaa teoksissaan omia tuska- ja kiputilojaan mutta kykenee myös analysoimaan niiden taustalta löytyviä yhteiskunnallisia syitä, kulttuurin naiselle asettamia rajoitteita.

Kolmas Kirsi Tuohelan tutkimista naisista on Laura Marholm (1854-1928), joka ei aivan ongelmattomasti asetu kahden edellä esitetyn rinnalle. Hän eroaa toisista, Kööpenhaminaan muuttavista naisista, pysytellen suurimman osan elämäänsä Saksassa. Hän ei vaikuta kovin masentuneeltakaan, mutta sairastuu kuitenkin äkillisesti ja parantumattomasti skitsofreniaan. Tosin hänen sairastumistaan ja sairastamistaan ei muista poiketen varsinaisesti edes käsitellä. Sen sijaan keskitytään naisten pienoiselämäkertoihin, joita Marholm kirjoitti - hän kirjoitti sekä Victoria Benedictssonista että Amalie Skramista - sekä tarkastellaan hyvin yksityiskohtaisesti hänen kirjoittamaansa näytelmää sekä teosta, jonka Marholm oli lukenut ja josta hän oli hyvin vaikuttunut. Tämä osio tuntuu kokonaisuuden kannalta hiukan turhalta tai vähintäänkin muista poikkeavalta. Tuohela pyrkii kyllä perustelemaan ratkaisunsa, mutta ei oikein vakuuta.

\section{MONIAINEISTOISUUS JA MONINÄKÖKULMAISUUS}

Monenlaiset aineistot ja monenlaiset lukutavat tuottavat hieman hajanaisen ja sirpaleisen kuvan. Työssä tarkastellaan hyvin erilaisia aineistoja ja erilaisiin teksteihin sovelletaan erilaisia lukutapoja, niille tehdään erilaisia kysymyksiä ja niihin vastataan eri tavoin. Toisaalta voidaan ajatella, että työ on tarkoituksella sirpaleinen ja moninäkökulmainen. Aineiston moninaisuus ja hajanaisuus sekä tulkintojen sirpaleisuus nostavat kiehtovalla tavalla esiin kysymyksen mennyttä koskevan tiedon muodostumisesta. Jopa nykyisyyttä koskeva tieto on aina näkökulmaista ja osittaista, mutta menneisyyttä koskeva tieto on sitä vielä enemmän. Meille säilyy vain kirjoitettua ja säilytettyä tietoa, 


\section{TiINA MAHLAMÄKI}

ei puhuttua, ei ajateltua, ei roskakoriin heitettyä. Voimme lukea vain niiden ihmisten ajatuksia, jotka halusivat ja kykenivät jäsentämään mietteitään kirjallisesti, jotka käyttivät tätä taitoa ja jotka säästivät tai julkaisivat kirjoittamansa tekstit. Vain heidän ajatuksensa jäävät eloon, meidän luettaviksemme. Tästä riipaisevana osoituksena on Tuohelan (s. 330-331) löytämä Berliinin kaupunginkirjaston tietokanta, joka merkitsee Laura Marholmin kuolinvuodeksi vuoden 1905, vuoden jolloin hän sairastui ja lopetti kirjoittamisen, vaikeni, eikä siis vuotta 1928, jolloin hän vasta kuoli.

Huhtikuun naisten aineistoja voisi ehkä tarkastella myös muistitietonäkökulmasta. Säilyneet tekstit tuottavat taitavan tutkijan käsissä meille kuvauksen elämästä, kirjoittamisesta ja kärsimisestä sellaisena kuin tutkittavat naiset sen kokivat ja muistivat. Tuo kuva on väistämättä vinoutunut, osin puutteellinen, suurelta osin näkökulmainen, mutta sellaista todellisen elämän kuvaus aina on. Kaunokirjallisuutta on nykyään useimmiten varoen - jos ollenkaan - tulkittu suorana tai edes etäännytettynä kuvauksena kirjoittajansa elämästä. Tuohela ottaa rohkeasti käsittelyynsä myös fiktiiviset tekstit etsien ja löytäen niistä yhdenmukaisuuksia kirjoittajiensa eletyn elämän kanssa, ja siksi tulkiten niiden ilmaisevan kirjoittajansa näkemyksiä naisesta, naisen paikasta ja naisen kärsimyksestä. Tulkinta on suurelta osin uskottava ja lukutapa perusteltua, mutta sellaiset fiktiiviset tekstit, joita tutkittavat naiset eivät ole itse tuottaneet, eivät olisi ehkä ansainneet niin yksityiskohtaista luentaa.

Kirsi Tuohelan väitöskirja Hubtikunn tekstit on kiehtova, rikastuttava lukukokemus, joka lisää ymmärrystä ja avaa uusia näköaloja paitsi naisen ja masennuksen suhteisiin myös omaelämäkerrallisten aineistojen uudenlaisiin käyttötapoihin.

\section{KirJallisuUs}

ELIO'T, T. S. 1972: Autio maa: neljä kvartettia ja muita runoja. Toimittaneet Lauri Viljanen ja Kai Laitinen. Helsinki: Otava.

GRÖNSTRAND, HEIDI 2005: Naiskirjailija, romaani ja kirjallisuusinstituntio 1840-luvun Suomessa. Helsinki: Suomalaisen Kirjallisuuden Seura.

KORTELAINEN, ANNA 2003: Levoton nainen. Hysterian kulttuuribistoriaa. Helsinki: Tammi.

LAUNIS, KATI 2005: Kerrotut naiset. Suomen ensimmäiset naisten kirjoittamat romaanit naiseuden määrittelijöinä. Helsinki: Suomalaisen Kirjallisuuden Seura.

LESKELÄ-KÄRKI, MAARIT 2006: Kirjoittaen maailmassa. Krohnin sisaretja kirjallinen elämä. Helsinki: SKS.

MELKAS, KUKKU 2006: Historia, halu ja tiedon käärme Aino Kallaksen tuotannossa. Helsinki: Suomalaisen Kirjallisuuden Seura.

Filosofian tohtori Tiina Mahlamäki on uskontotieteen tutkija Turun yliopiston kulttuurien tutkimuksen laitoksessa. 